Article

\title{
Nanotechnology, Green Synthesis and Biological Activity Application of Zinc Oxide Nanoparticles Incorporated Argemone Mxicana Leaf Extract
}

\author{
Maheswari Chinnapaiyan ${ }^{1,2}$, Yashika Selvam ${ }^{3}$, Fatma Bassyouni ${ }^{4} * \mathbb{D}$, Mathammal Ramu ${ }^{1}$, \\ Chandrasekar Sakkaraiveeranan ${ }^{2}$, Aravindan Samickannian ${ }^{5}$, Gobi Govindan ${ }^{5}$, Matheswaran Palaniswamy ${ }^{6}$, \\ Uthrakumar Ramamurthy ${ }^{5}$ and Mohamed Abdel-Rehim ${ }^{7}$ (D)
}

check for updates

Citation: Chinnapaiyan, M.; Selvam, Y.; Bassyouni, F.; Ramu, M.; Sakkaraiveeranan, C.; Samickannian, A.; Govindan, G.; Palaniswamy, M.; Ramamurthy, U.; Abdel-Rehim, M. Nanotechnology, Green Synthesis and Biological Activity Application of Zinc Oxide Nanoparticles Incorporated Argemone Mxicana Leaf Extract. Molecules 2022, 27, 1545. https://doi.org/10.3390/ molecules 27051545

Academic Editor: Ashok Kakkar

Received: 30 December 2021 Accepted: 21 February 2022 Published: 25 February 2022

Publisher's Note: MDPI stays neutral with regard to jurisdictional claims in published maps and institutional affiliations.

Copyright: (C) 2022 by the authors. Licensee MDPI, Basel, Switzerland. This article is an open access article distributed under the terms and conditions of the Creative Commons Attribution (CC BY) license (https:// creativecommons.org/licenses/by/ $4.0 /)$.
1 Department of Mathematics, Muthayammal College of Arts and Science, Rasipuram 637408, Tamil Nadu, India; mahi2gobi@gmail.com (M.C.); mathammalphy18@gmail.com (M.R.)

2 PG \& Research Department of Mathematics, Arignar Anna Government Arts College, Namakkal 637002, Tamil Nadu, India; chandrumat@gmail.com

3 Department of Physics, Sri Sarada College for Women (Autonomous), Salem 636016, Tamil Nadu, India; yashikaphy@gmail.com

4 Department of Natural and Microbial Products, National Research Center, Cairo 12662, Egypt

5 Department of Physics, Government Arts College (Autonomous), Salem 636007, Tamil Nadu, India; aravindan.sp@gmail.com (A.S.); gobi.rect@gmail.com (G.G.); ukloyola@gmail.com (U.R.)

6 Department of Chemistry, Government Arts College (Autonomous), Salem 636007, Tamil Nadu, India; matheshkutty77@gmail.com

7 Department of Materials and Nanophysics, KTH Royal Institute of Technology, SE-11419 Stockholm, Sweden; mohamed.astra@gmail.com

* Correspondence: fatma.nrc.eg@gmail.com

\begin{abstract}
Nanomaterial is a rapidly growing area that is used to create a variety of new materials and nanotechnology applications from medical, pharmaceuticals, chemical, mechanical, electronics and several environmental industries including physical, chemical and biological nanoparticles are very important in our daily life. Nanoparticles with leaf extract from the healthy plant are important in the area of research using biosynthesis methods. Because of it's used as an environmentally ecofriendly, other than traditional physical and chemical strategies. In particular, biologically synthesized nanoparticles have become a key branch of nanotechnology. The present work presents a synthesis of zinc oxide nanoparticles using an extract from the Argemone leaf Mexicana. Biosynthetic nanoparticles are characterized by X-ray diffraction (XRD), Ultraviolet visible (UV-vis) spectroscopy analysis, a Fourier Transform Infrared Spectroscopy analysis (FTIR) and a scanning electron microcopy (SEM), X-ray analysis with dispersive energy (EDAX). XRD is used to examine the crystalline size of zinc oxide nanoparticles. The FTIR test consists in providing evidence of the presence of targeted teams. UV is used for optical properties and calculates the energy of the bandwidth slot. The scanning microscope emission reveals the morphology of the surface and the energy dispersive X-ray analysis confirms the basic composition of zinc oxide nanoparticles. It is found that zinc nanoparticles are capable of achieving high anti-fungal efficacy and therefore have a high potential antimicrobial activity of ZnO NPs, like antibacterial and high antioxidant. Zinc Oxide nanoparticles from the Argemone Mexicana leaf extract have several antimicrobial applications, such as medical specialty, cosmetics, food, biotechnology, nano medicine and drug delivery system. $\mathrm{ZnO}$ nanoparticles are important because they provide many practical applications in industry. The most important use of nanoparticles of $\mathrm{ZnO}$ would be strong antibacterial and antioxidant activity with a simple and efficient biosynthesis method may be used for future work applications.
\end{abstract}

Keywords: nanoparticles ZnO NPs; green biosynthesis; characterization techniques; antibacterial and antifungal activities; antioxidant activity 


\section{Introduction}

Nanotechnology is the most important dynamic exploration regions in the current of material science. Nanoparticles have entirely new and more developed research based on specific factors such as size, dispersion and morphology. Nanotechnology technique is an area that develops day-to-day, and affecting all parts of the human existence [1-3]. Nano zinc particles have found surprising applications in the field of high molecular identification and demonstration [4], antimicrobials, therapeutics [5,6], catalytic converters [7] and miniature equipment [8]. However, there is still a requirement for application in industrial expert and a widely approach to the integration of zinc nanoparticles. Numerous techniques applied, for example, the combination of zinc nanoparticles, the reaction of substances and the reaction of compounds changing micelles, the extensively used of zinc oxide in radiation [9-12], the electrochemical, sonochemical, microwave [13-15] and green science applications [16-18].

Natural techniques have been prepared for a "greener Union" of nanoparticles and have been shown to be more efficient due to their slower energy, giving better focus product and control over the development and reliability of valuable compounds economically, scientifically and environmentally valuable compounds and materials in nanostructure form.

This has strengthened of an important of nanotechnology pathway, which includes better control of the shape and size of various nano-applications. The uses in microscopic and micro sheet applications have increased as well as used as antimicrobial and antifungal agents in addition to nano medicine and as catalysts [19-22]. Zinc nanoparticles offer numerous environmental benefits and similarities of medicines to other natural uses. The green compound is improving for substances and real techniques are increasing, ecofriendly, accurately estimated in large quantities and there is no convincing reason to use high pressures, energy, temperature and synthesis. It has been known for a long time that zinc is caused by the presence of inhibitory organisms used in the clinical and modern system. Nanopharmaceutical, including drug and medical nanomaterial, and useful nanoparticles used as anti-microbial agents or functional nanostructures used for the detection of biomarkers, nano chips, nanoparticles are very important in our life in the application of nanotechnologies [23,24]. The main use of zinc nanoparticles and zinc oxides is in clinical and biomedical applications as well as the supply of medicines, drug delivery and biosensor [25].

Argemone Mexicana is a medical plant is shown in Figure 1 and can be used to treat various diseases as fever, malaria, jaundice, vagina, skin diseases. It is widely distributed in India and grown in the garden and on the road side, wild boar in the hills of north-western India. Argemone is botanically classified with two Latin names, namely Mexican mushroom and satranishi. The species of Argemone Mexicana Linn is subject to the family Papaveracea and the name of the species in Tamil is Bramatandu. The plant is used in various parts of the world to treat several conditions, including cancer, osnowiec, skin disease, inflammation, rheumatism, jaundice, tritzies, microbiological infections and malaria. Interestingly, the plant is a source of various kinds of chemical ingredients, although alkaloids are mostly rich. Therefore, this work reveals the synthesis and examines the properties of zinc oxide nanoparticles, using the extract from the leaves of Argemone Mexicana as cheaper natural products, particularly suitable for the medicinal compounds [26,27].

In the present study, we report a combination of nanoparticles of zinc and reducing the zinc particles present in zinc acetic acid derivative arrangement by the fluid extraction of the AML. These nanoparticles have been discovered to be profoundly their leaves and are deeply active against various pathogenic microscopic organisms as antimicrobial and antioxidant agents. 


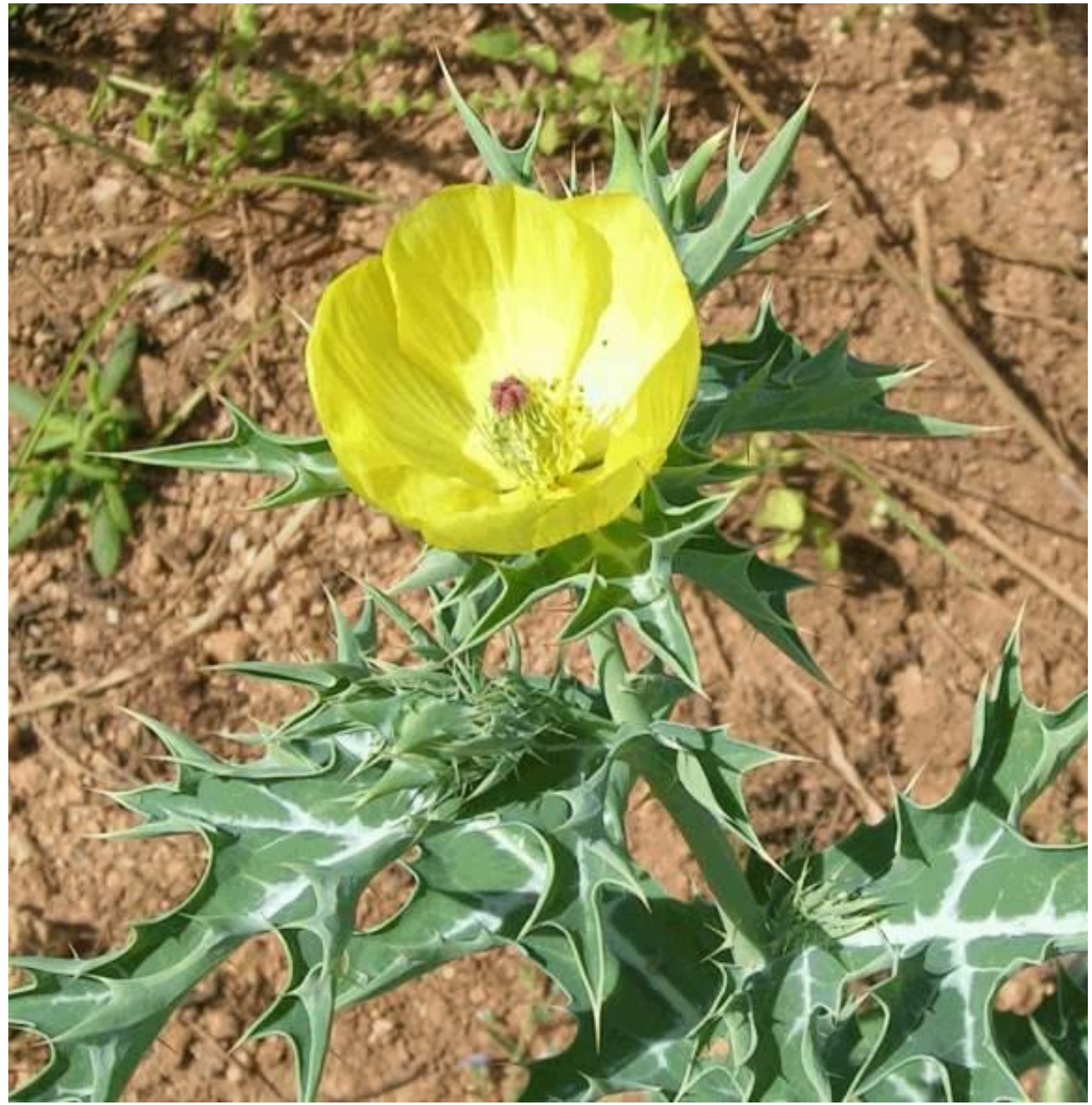

Figure 1. Image of Argemone Mexicana Plant.

\section{Results and Discussion}

\subsection{X-ray Diffraction Analysis}

Analysis of the X-ray diffraction (XRD) helps to ensure that zinc oxide nanoparticles are formed from the extract solution of the leaves of $\mathrm{ZnO}$ and Argemone Mexicana (AML). The XRD zinc powder pattern is shown in (Figure 2), showing the diffraction peaks of the $\mathrm{ZnO}$ crystal structure in specific phases. The acute peaks of the XRD pattern indicate the well-organized crystalline nature of the yield product. The data are some specific crystalline peaks that are well agreed with the JCPDS Charter No 89-1397 the emergence of the $\mathrm{ZnO}$ nano-structure has been ensured. The diffraction mesh planes belong to crystalline peaks, as shown in (Figure 2), are indexed as (100), (002), (101), (102), (110), (103), and (202) in turn confirmed the hexagonal structure of $\mathrm{ZnO}$ nanoparticles. This formula is consistent with the standard peak values displayed by the International Diffractive Data Center (IDDC). The average size of crystalline zinc nano particles was estimated on the basis of data from the formation of crystalline peaks. The observed XRD test results shall examine the well-organized crystalline structure of the yield product as a result of the use of the raw processing product including the Argemonac Mexicana leaf extract (AML). It proves the product that is being developed materials, the results showed in Figure 2 and Table 1. 


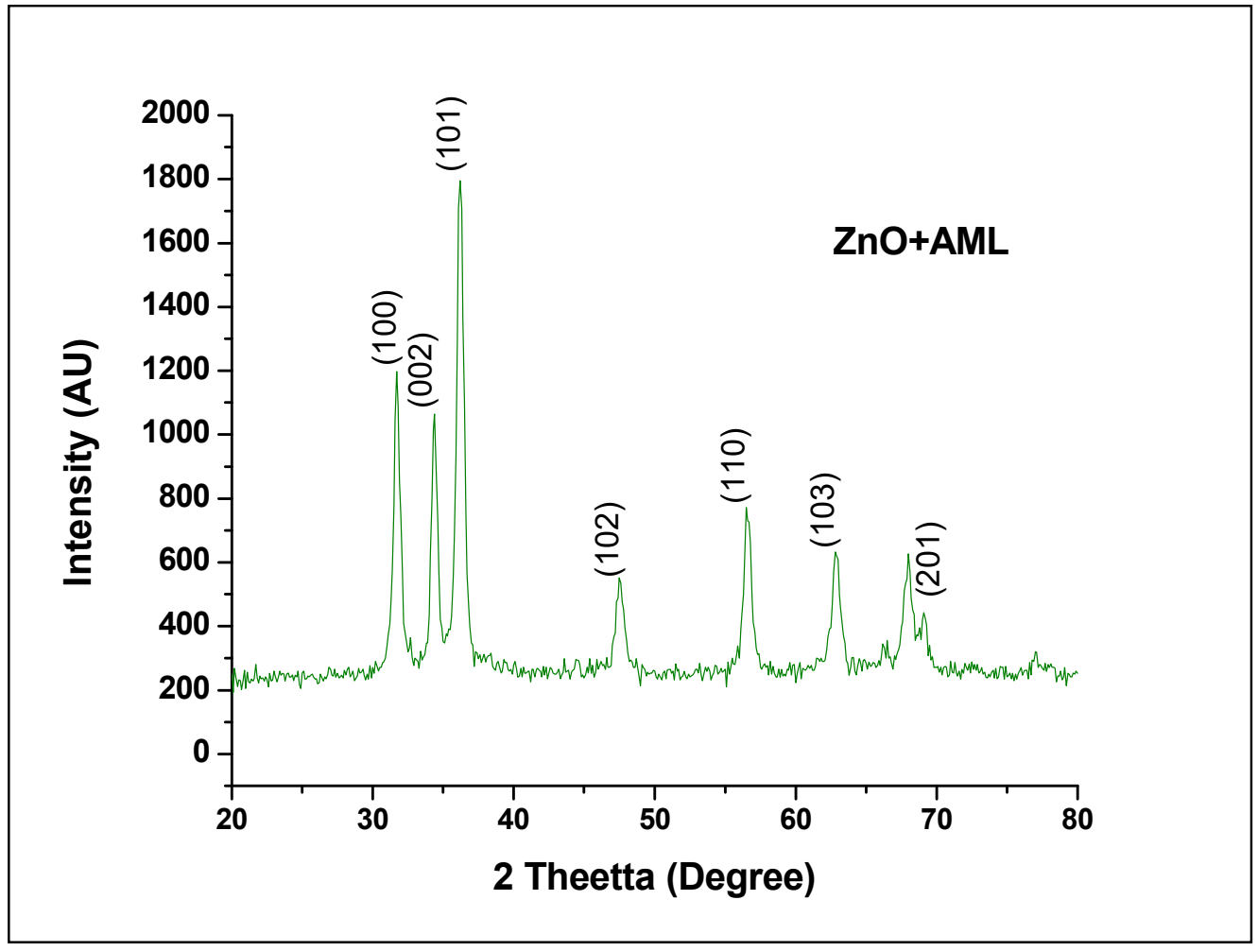

Figure 2. XRD analyses of zinc oxide nanoparticles (ZNP) with indexed crystalline peaks.

Table 1. Crystalline size and hkl value of observed crystalline peaks.

\begin{tabular}{|c|c|c|c|c|c|c|}
\hline S.NO & $2 \theta$ Degree & $\mathrm{d} \mathrm{A}^{\circ}$ & FWHM (deg) & Hkl & $\begin{array}{l}\text { Crystalline } \\
\text { Size (nm) }\end{array}$ & $\begin{array}{l}\text { Average Crystal } \\
\text { Size }(\mathrm{nm})\end{array}$ \\
\hline 1. & 31.737 & 2.820 & 0.56300 & 100 & 1.47129 & \\
\hline 2. & 34.379 & 2.608 & 0.54300 & 002 & 1.532493 & 1.461449 \\
\hline 3. & 36.215 & 2.480 & 0.60570 & 101 & 1.380564 & \\
\hline
\end{tabular}

where,

$\mathrm{k}=$ Scherrer's constant (0.9)

$\lambda=$ Wavelength of X-ray $\left(1.54 \times 10^{-10} \mathrm{~m}\right)$

$\beta=$ Full Width Half Maximum

$\theta=$ Bragg's angle

The particle size of zinc oxide Nano particles is $1.46 \mathrm{Nm}$

\subsection{FTIR Analysis}

Infrared spectroscopy analysis with Fourier transformation helps to investigate the functional behavior of sample peaks. It is well known that the optical response of molecular species in the form of vibrations followed by the absorption of the IR signal is recorded as a spectral analysis, as shown in Figure 3. The elemental components of zinc oxide nanoparticles reacted well to the IR signal by displaying the absorbance. 


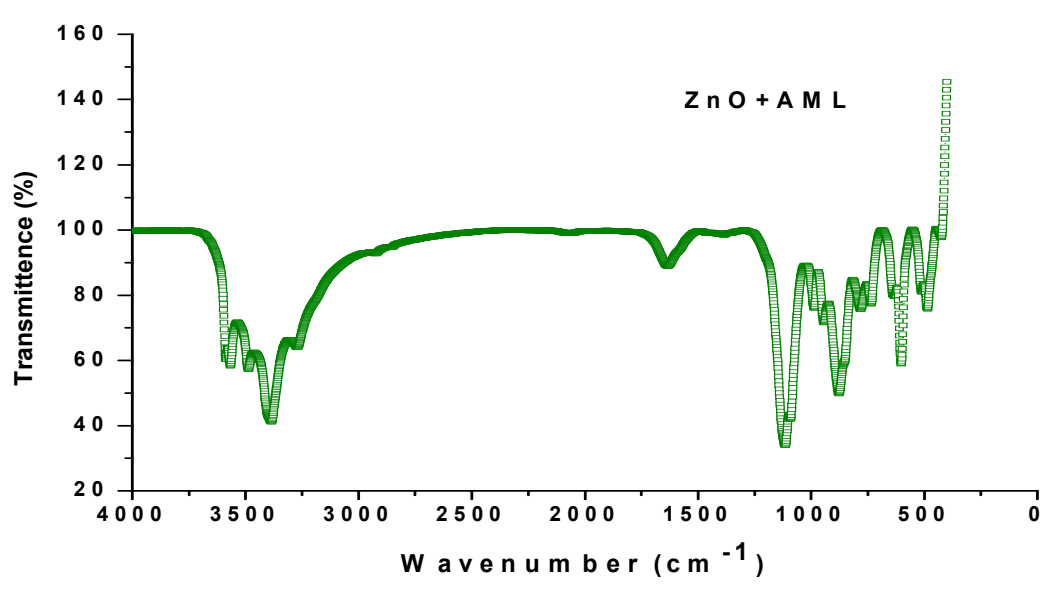

Figure 3. FTIR analyses of zinc oxide nanoparticles (ZNP).

The FTIR spectrum is shown in Figure 3, the peaks observed at distances of 1650 and $3353 \mathrm{~cm}^{-1}$ contribute to bending and stretching the moisture vibrations present in the which is seen in spectral peak in the form of absorbance assigned to leaf extract, and was observed in the region of 3196, 1650, 1102 and $871 \mathrm{~cm}^{-1}$. The exhibited absorption bands, especially in the corresponding rang 3353, $3196 \mathrm{~cm}^{-1}$ (phenol O-H), $1626 \mathrm{~cm}^{-1}$ of $(\mathrm{C}=\mathrm{C}$ ), $1650 \mathrm{~cm}^{-1}$ for $(\mathrm{C}=\mathrm{N}), 1102 \mathrm{~cm}^{-1}$ for $(\mathrm{C}-\mathrm{O})$ and $871(\mathrm{C}=\mathrm{C}$ bending $)$, proves the existence of synthetic and atmospheric solution residue Table 2.

Table 2. FTIR Peak Values.

\begin{tabular}{cc}
\hline Peak Value & Chemical Bonding \\
\hline $871 \mathrm{~cm}^{-1}$ & $\mathrm{C}=\mathrm{C}$ bending \\
\hline $3196 \mathrm{~cm}^{-1}$ & $\mathrm{O}=$ H Stretching \\
\hline $1626 \mathrm{~cm}^{-1}$ & $\mathrm{C}=\mathrm{C}$ Stretching \\
\hline $1650 \mathrm{~cm}^{-1}$ & $\mathrm{C}=\mathrm{N}$ Stretching \\
\hline $1102 \mathrm{~cm}^{-1}$ & $\mathrm{C}-\mathrm{O}$ Stretching \\
\hline
\end{tabular}

\subsection{Scanning Electron Microscopic Analysis (SEM)}

Electron microscopy of microscopic analysis SEM used to examine the shape, structure and size of synthesized ZNP as shown in Figure 4a,b. The results of the SEM show that, at different magnification, nanoparticles are of size and shape. As can be seen from the use of zinc acetate as a result, the zinc oxide molecules grow slowly and form small spherical structures and accumulate like spheres. On the other hand, using zinc nitrate as a spring, spherical ZNP is formed and nanoparticles grow and accumulate to form flowershaped beams. This agglomeration is due to the polarity and electrostatic attraction of $\mathrm{ZnO}$ nanoparticles. Similar observations were documented by Divya et al. [28].in the current study on the green synthesis of ZNP by Argemone Mexicana, the leaf in water extract and zinc acetate as precursors, the shapes of nanoparticles were like flower bunches. As seen, the image indicates that the particles were present in both diffuse and agglomerated mono with approximately spherical morphology. Such variations in particle size and shape distribution can be explained by the chemical structures of the various components contained in plant extracts Figure 4a,b. 

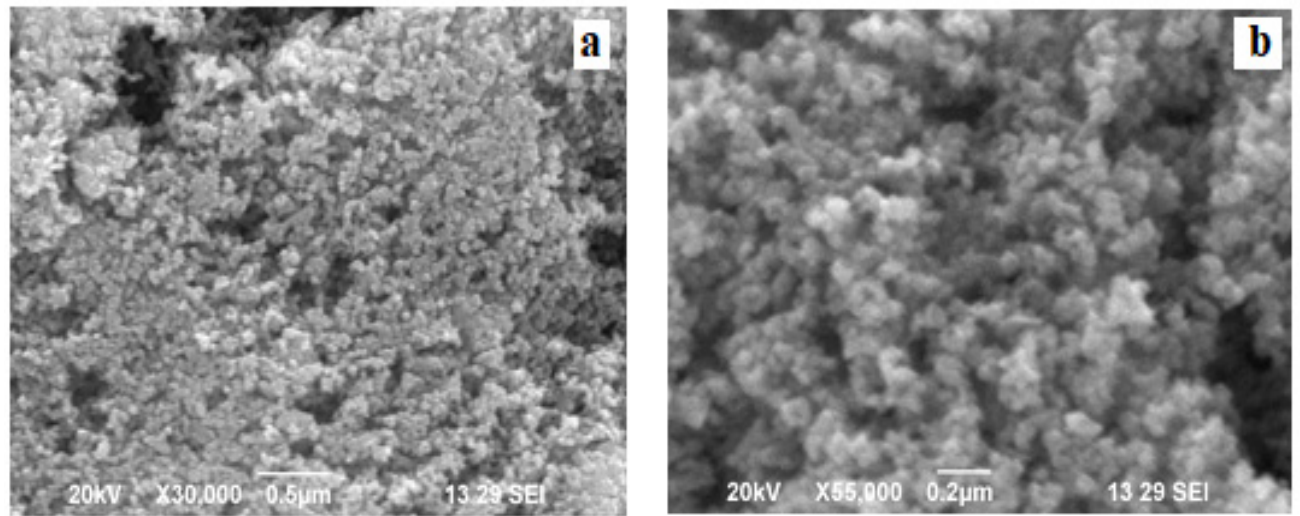

Figure 4. (a,b) SEM micrographs of ZnO nanoparticles with AML.

\subsection{Energy-Dispersive X-ray Spectroscopy}

The analysis of the elemental composition of the ZNP from the EDAX graph, as shown in Figure 5, reveals that the elemental components of the samples are present on the surface. The EDAX spectrum shows that the required $\mathrm{Zn}$ and $\mathrm{O}$ phase is present in the samples and confirms high purity for synthesized ZNP. The hypothetical expected percentage of stoichiometric is $32.05 \%$ and $34.58 \%$ respectively. The analysis of EDAX in our study shows similar results for both synthesized nano particles, while in the previous study the elemental composition of zinc and oxygen was $60.16 \%$ and $12.87 \%$ [29], respectively. The existence of $\mathrm{OH}$ components records the rewinding components existing on the sample surface. Since the EDAX analysis observed in the SEM analysis, the particles that appear in the SEM images are provided as components of zinc nanoparticles. As expected, the percentage of $\mathrm{Zn}$ above the oxygen content is dominant and confirms that the prepared samples are a product of zinc oxide nanoparticles prepared under the influence of an AML extract (Figure 5 and Table 3).

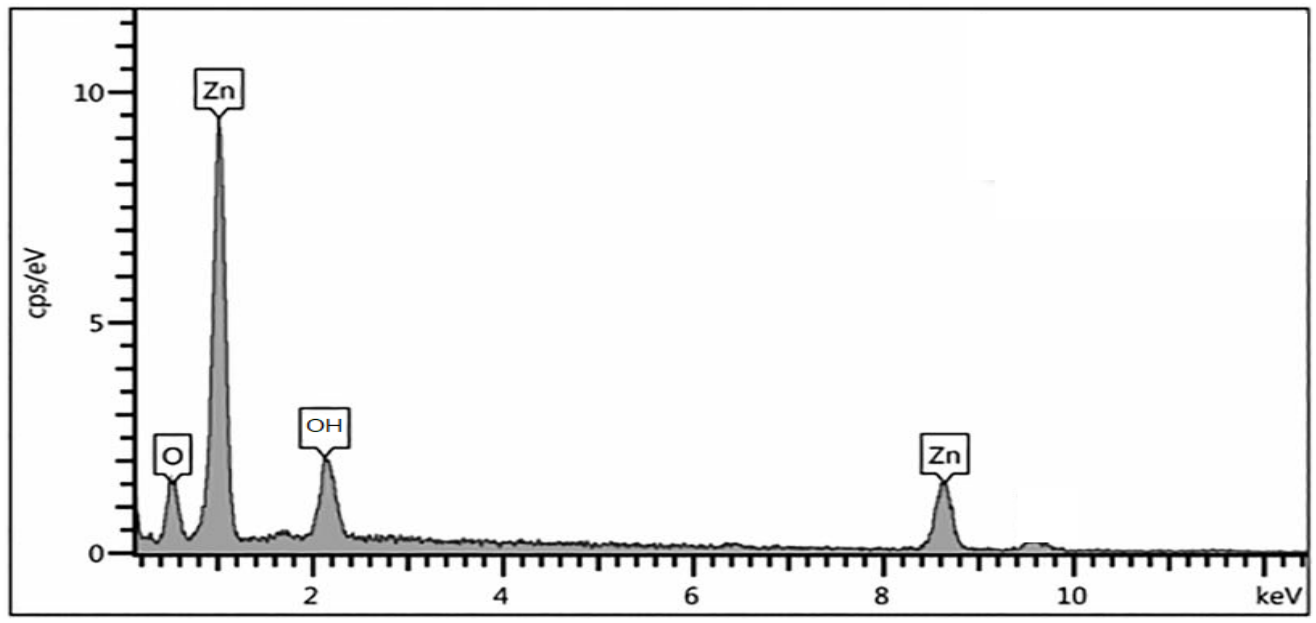

Figure 5. EDAX Spectrum of Zno Nps.

Table 3. EDAX Analysis for Zinc Nanoparticles.

\begin{tabular}{ccc}
\hline Sample & At of $(\mathbf{Z n})$ & At of $(\mathbf{O})$ \\
\hline $\mathrm{ZNp}$ & 32.05 & 34.58 \\
\hline
\end{tabular}

\subsection{Ultraviolet—Visible (UV-Vis) Spectroscopy}

Spectral analyzes used to test the performance of elemental components exist in the sample. Ultra Violet-visible (UV-vis.) Spectroscopy analysis is a visible observation that 
can be used to examine the electronic configuration of the root structure. It is well known that $\mathrm{ZnO}$ has an absorption edge in the wavelength range 200 to $400 \mathrm{~nm}$. UV-vis observed. The spectrum shows the peak absorption around the wavelength of $377 \mathrm{~nm}$ and records the adsorption of the electronic $\mathrm{ZnO}$ bandwidth gap. This result is a good agreement with the values $\mathrm{eV}$ and will investigate the cause of the removal of the Valencia electron. The estimated value of the gap in the electronic energy band is $3.2 \mathrm{eV}$ and ensured the creation of a crystalline structure of Nano $\mathrm{ZnO}$ with a reduced value of the band gap. The $\mathrm{ZnO}$ bandwidth value is approximately $3.57 \mathrm{eV}$, which is estimated in the work. Results show a reduction in the nano-scale $\mathrm{ZnO}$ particle size. The present value clearly showed a significant decrease in the bandwidth gap as $3.2 \mathrm{eV}$ as shown in Figure 6.

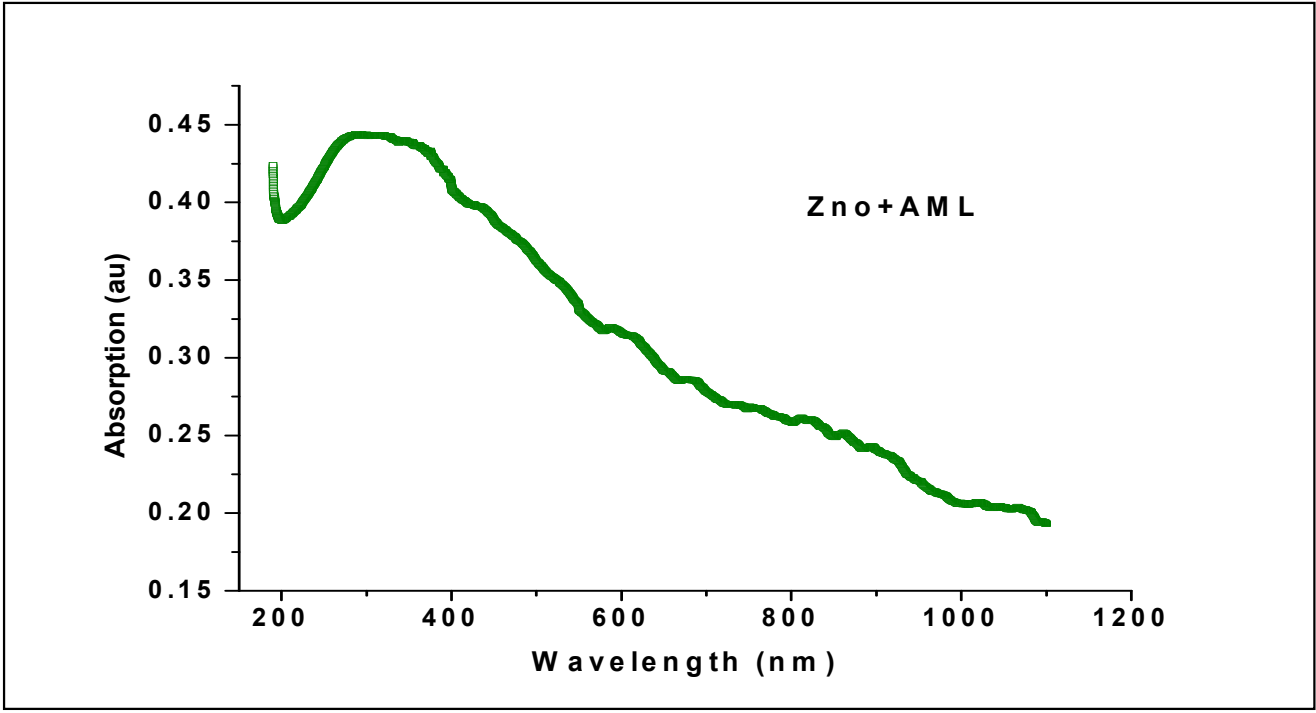

Figure 6. UV-Visible Spectrum of $\mathrm{ZnO} \mathrm{Nps}$.

\subsection{Antibacterial Activity}

From the anti-microbial test, the activity of synthetic extracts of ZnO NPs and leaves gave very good inhibits growth of both $E$. coli and S.aureus and the results are summarized in the Table 4. Leaf extract as well as high ZnO NPs concentration gives high activity. The E. coli organism inhibition zone is larger than zone S.aureus with a ZnO NPs concentration of $75 \mu \mathrm{L}$ and $100 \mu \mathrm{L}$. The anti-microbial activity of the synthesized ZnO NPs is expressed as a potential activity than pure leaf extract. Since zinc ions exposed to leaf extract have a greater for action. The synthetic ZnO NPs shows the maximum inhibitory effect against both Gram positive bacteria and Gram-negative bacteria (E. coli and Staphylococcus aureus). The anti-microbial activity of ZnO NPs has a standard E. coli inhibition zone of 8 to $11 \mathrm{~mm}$ and Staphylococcus aureus from $7 \mathrm{~mm}$ inhibition zone. The respective concentration is $75 \mu \mathrm{L}$ and $100 \mu \mathrm{L}$ for both organisms.

Table 4. Antibacterial activity of $\mathrm{ZnO}$ against Escherichia coli and Staphylococcus aureus.

\begin{tabular}{|c|c|c|c|c|}
\hline \multirow{2}{*}{ Sample No } & \multirow{2}{*}{$\begin{array}{l}\text { Sample } \\
\text { Marking }\end{array}$} & \multirow{2}{*}{$\begin{array}{c}\text { Sample } \\
\text { Concentration }\end{array}$} & \multicolumn{2}{|c|}{$\begin{array}{l}\text { Test Organisms and Zone of } \\
\text { Inhibition in }(\mathrm{mm})\end{array}$} \\
\hline & & & $\begin{array}{c}\text { Staphylococcus } \\
\text { aureus }\end{array}$ & E. coli \\
\hline 2 & Control & MHA & NA & NA \\
\hline 3 & \multirow{2}{*}{ Leaf Extract } & $75 \mu \mathrm{L}$ & NA & $8 \mathrm{~mm}$ \\
\hline 4 & & $100 \mu \mathrm{L}$ & $7 \mathrm{~mm}$ & $11 \mathrm{~mm}$ \\
\hline
\end{tabular}




\subsection{Antifungal Activity}

The anti-fungal properties of the ZnO NPS, the results indicate that zinc nanoparticles have good anti-fungal activity against the Aspergillus fumigate micro-organism. It is confirmed that zinc nanoparticles are capable of achieving high anti-fungal efficacy and therefore have a high potential activity of $\mathrm{ZnO}$ NPs, which is clearly visible in the inhibition zone by the growth of the tested micro-organisms in Table 5.

Table 5. Antifungal activity of $\mathrm{ZnO}$ nanoparticles.

\begin{tabular}{cccc}
\hline Sample No & Sample Marking & $\begin{array}{c}\text { Sample } \\
\text { Concentration }\end{array}$ & $\begin{array}{c}\text { Zone of Inhibition } \\
\text { in (mm) }\end{array}$ \\
\cline { 1 - 3 } 2 & Control & PDA & Aspergillus fumiga \\
\hline 3 & \multirow{2}{*}{ ZnO AML } & $25 \mu \mathrm{L}$ & $5 \mathrm{~mm}$ \\
\cline { 3 - 4 } 4 & \multirow{2}{*}{ Leaf Extract } & $75 \mu \mathrm{L}$ & $\mathrm{NA}$ \\
\hline 5 & & $50 \mu \mathrm{L}$ & $\mathrm{NA}$ \\
\hline 6 & & $100 \mu \mathrm{L}$ & $13 \mathrm{~mm}$ \\
\hline
\end{tabular}

Figure 7 shows the action of the synthetic $\mathrm{ZnO}$ NPs from the plant extract Argemone Mexicana against Aspergillus fumiga.

\subsection{Antioxidant Activity}

The results are shown in Table 6. The relative braking zone of the sample is shown in Figure 8 . The sample exhibited significant activity at the lowest concentration of $\mathrm{IC}_{50}$. The color changes from purple to yellow. Ascorbic acid has been used as a standard with an $\mathrm{IC}_{50}$ value of $92 \pm 0.1 \mu \mathrm{g} / \mathrm{mL}$. The absorption values of the $\mathrm{IC}_{50}$ ascorbic acid are shown in Table 7. The relative braking zone of the sample is shown in Figure 8. A lower absorbance value and $\mathrm{IC}_{50}$ indicated that NPS $\mathrm{ZnO}$ has anti-oxidative properties.

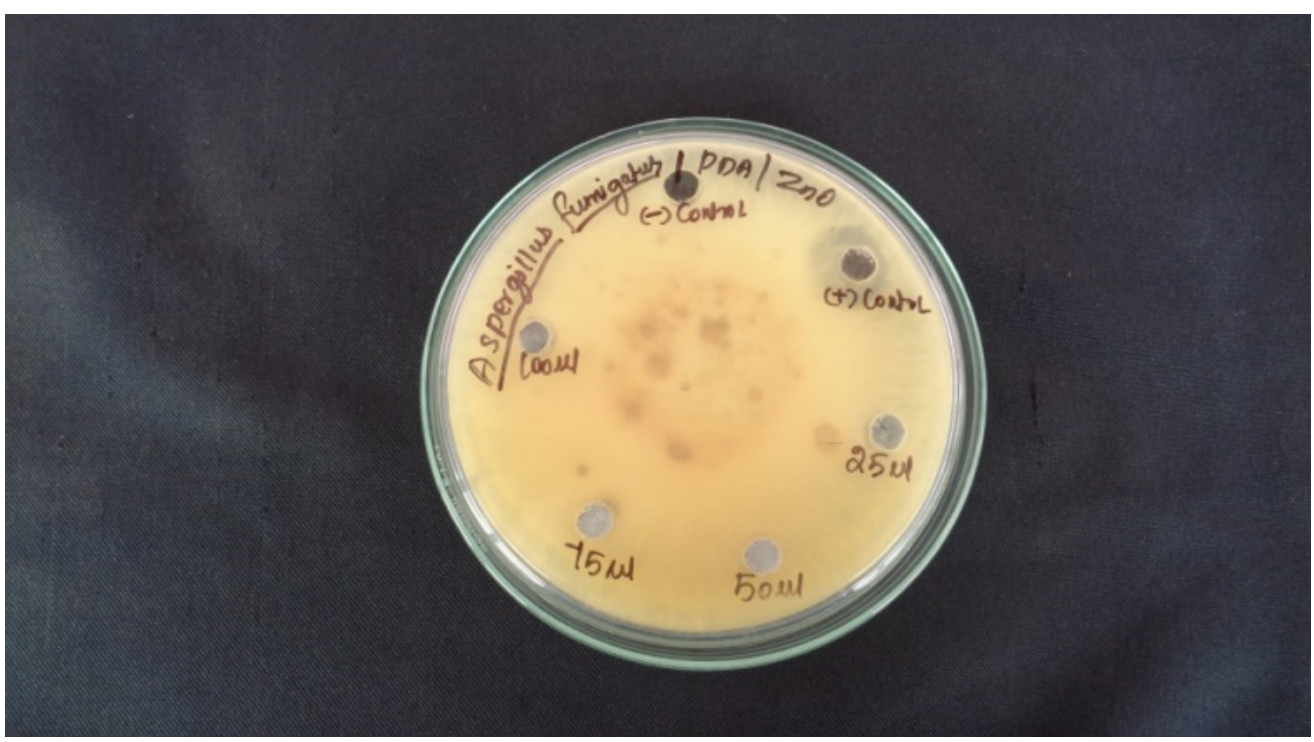

Figure 7. Antibacterial activity of $\mathrm{ZnO} \mathrm{Nps}$ and Leaf extract. 
Table 6. The Percentage inhibition of Argemone Mexicana Leaf Extract.

\begin{tabular}{|c|c|c|c|c|}
\hline \multirow{3}{*}{$\begin{array}{c}\text { Sample No } \\
1 \\
\end{array}$} & \multirow{3}{*}{$\begin{array}{l}\text { Extract Concentration }(\mu \mathrm{g} / \mathrm{mL}) \\
\qquad 500 \mu \mathrm{g} / \mathrm{mL}\end{array}$} & \multicolumn{3}{|c|}{ DPPH Antioxidant Activity } \\
\hline & & \multicolumn{3}{|c|}{$\begin{array}{l}\text { OD Value at } 517 \mathrm{~nm} \\
\text { (in Triplicates) }\end{array}$} \\
\hline & & 1.613 & 1.244 & 1.507 \\
\hline 2 & $250 \mu \mathrm{g} / \mathrm{mL}$ & 0.108 & 0.120 & 0.122 \\
\hline 3 & $100 \mu \mathrm{g} / \mathrm{mL}$ & 0.152 & 0.153 & 0.198 \\
\hline 4 & $50 \mu \mathrm{g} / \mathrm{mL}$ & 0.211 & 0.236 & 0.247 \\
\hline 5 & $10 \mu \mathrm{g} / \mathrm{mL}$ & 0.283 & 0.253 & 0.273 \\
\hline 6 & Control & 1.189 & 1.148 & 1.116 \\
\hline
\end{tabular}

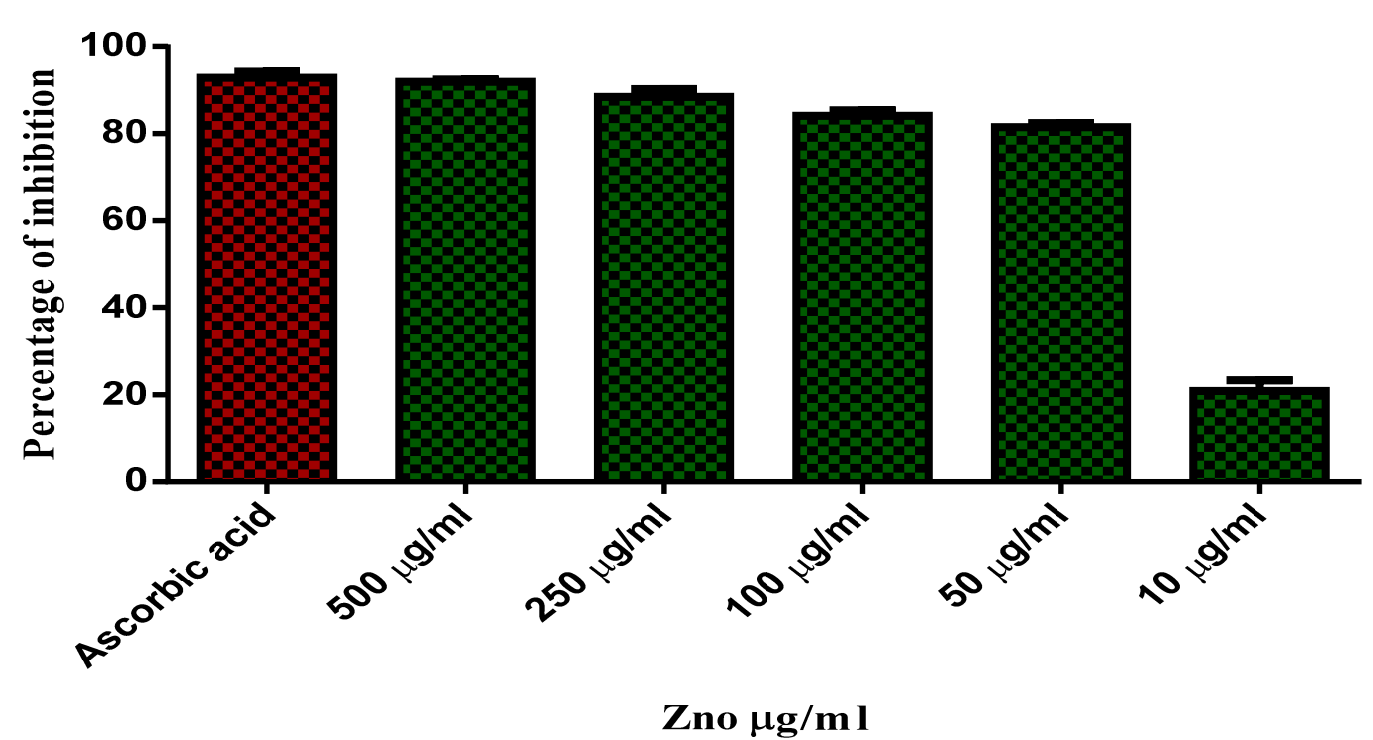

Figure 8. The Percentage inhibition concentration of Ascorbic acid.

Table 7. The Percentage inhibition and $\mathrm{IC}_{50}$ value of Ascorbic acid.

\begin{tabular}{|c|c|c|c|}
\hline \multirow{2}{*}{ Sample No } & \multirow{2}{*}{ Standard } & \multirow[t]{2}{*}{ Concentration $(\mathrm{g} / \mathrm{mL})$} & $\begin{array}{l}\text { Antioxidant Activity } \\
\% \text { of Inhibition }\end{array}$ \\
\hline & & & DPPH (510 nm) \\
\hline 1 & \multirow{5}{*}{$\begin{array}{l}\text { Ascorbic acid used as } \\
\text { a standard (OD value) }\end{array}$} & $500 \mu \mathrm{g} / \mathrm{mL}$ & 91.97 \\
\hline 2 & & $250 \mu \mathrm{g} / \mathrm{mL}$ & 88.46 \\
\hline 3 & & $100 \mu \mathrm{g} / \mathrm{mL}$ & 84.08 \\
\hline 4 & & $50 \mu \mathrm{g} / \mathrm{mL}$ & 81.44 \\
\hline 5 & & $10 \mu \mathrm{g} / \mathrm{mL}$ & 20.83 \\
\hline
\end{tabular}

\section{Materials and Methods}

\subsection{Preparation of Leaf Extract}

The green and fresh leaves of Argemone Mexicana are carefully washed from tap water and double distilled water. Then $10 \mathrm{~g}$ of leaves were collected and ground into the leaf extract with a mortar and add $50 \mathrm{~mL}$ of distilled water and $20 \mathrm{~min}$ mixed. After $20 \mathrm{~min}$, a pure leaf extract of $10 \mathrm{~mL}$ is collected by the beaker solutions, filtered through whatman filter paper No 1 and used. 


\subsection{Biosynthesis of Zinc Oxide Nanoparticle}

The zinc acetate dihydrate was prepared by dissolving $3.8 \mathrm{~g}\left(\mathrm{CH}_{3} \mathrm{COO}\right)_{2} \mathrm{Zn}^{+} 2 \mathrm{H}_{2} \mathrm{O}$ in $50 \mathrm{~mL}$ of double distilled water and mixed for half an hour. Then $10 \mathrm{~mL}$ of the extract from the solution is added to the $\mathrm{Zn}$ acetate solution, leaving a drop by drop and stirring for two hours until nanoparticles are formed. The PH value is maintained at 12 by the addition of $\mathrm{NaOH}$. Finally, the color of the solution changes from a deep-low-level green colored paste. Nanoparticles are deposited at the bottom of the beaker. The clear solution is removed and therefore the particles are thoroughly rinsed twice daily with distilled water for four days. The extract solution is then removed and the particles are collected and placed over a furnace of hot air at low temperature for $100{ }^{\circ} \mathrm{C}$ for five hours. After the sample has been transferred to silica crucible cup and muffle furnace at $400{ }^{\circ} \mathrm{C}$ for $2 \mathrm{~h}$, the sample has finally been taken to the mortar and ground in a fine nano powder. These powdered nanoparticles have been used for characterization purposes (Table 8).

Table 8. Details of green biosynthesis experiment procedure.

\begin{tabular}{cll}
\hline Day & \multicolumn{1}{c}{ Materials and Methods } & \multicolumn{1}{c}{ Process } \\
\hline & $\begin{array}{l}\text { 3.8 g of Zinc acetate dihydrate+ } \\
50 \mathrm{~mL} \text { of distilled water }\end{array}$ & Stirred for $30 \mathrm{~min}$. \\
\cline { 2 - 3 } I & $\begin{array}{l}\text { 10 g leaves of Argemone maxicana+50 } \mathrm{mL} \\
\text { of distilled adding } 60 \mathrm{~mL} \text { of leaf extract } \\
\text { (drop wise) }\end{array}$ & $\begin{array}{l}\text { Stirred for } 20 \mathrm{~min}+\text { Filtering extract with } \\
\text { whatmann filter paper. }\end{array}$ \\
\cline { 2 - 3 } & $\begin{array}{l}\text { Formation of Zinc nanoparticles (deep } \\
\text { emerald green color) }\end{array}$ & $\begin{array}{l}\text { 1hour of stirring }(\mathrm{PH}=12) \text { and then kept in } \\
\text { room temp. }\end{array}$ \\
\hline II & $\begin{array}{l}\text { Deep emerald green precipitation } \\
\text { was formed }\end{array}$ & Per day for Two times water changed. \\
\hline III $\quad \begin{array}{l}\text { Deep emerald green precipitation } \\
\text { was formed }\end{array}$ & Per day for Two times water changed. \\
\hline IV $\quad \begin{array}{l}\text { Dried in hot air oven at } 100^{\circ} \mathrm{C} \text { for } \\
\text { Five hour }\end{array}$ & Sample transferred to silica crucible cup. \\
\hline V & $\begin{array}{l}\text { Heated in muffle furnace at } 400{ }^{\circ} \mathrm{C} \text { for } 2 \mathrm{~h} . \\
\text { White precipitation was formed finally. }\end{array}$ & Grained in mortar ZnO Nano powder. \\
\hline
\end{tabular}

\subsection{Antibacterial Activity Assay}

The Nanoparticles of oxide have been active in relation to Gram positive and Gramnegative bacteria, with a high degree of $100 \mu \mathrm{g}$, guided by the diameter of the inhibition zone. The braking zone is detected with the leaf extract (Argemone Mexicana) and a better concentration of zinc nanoparticles $(100 \mathrm{mg} / \mathrm{mL})$. The presence of a braking zone clearly indicates the outcome of the treatment of nanoparticles of $\mathrm{ZnO}$. It was noted that the concentration of nanoparticles of $\mathrm{ZnO}$ is increased; the expansion inhibition was also increased. The dimensions of the braking zone are completely different depending on the type of bacteria, the dimensions and the concentration of nanoparticles of $\mathrm{ZnO}$ [30,31].

\subsection{Antifungal Activity Assay}

The anti-fungal properties of the ZnO NPS solution of leaf extract were determined using Aspergillus fumiga, anti-fungal activity in diffusion assay method and its signs of growth of fungi in the diffusion assay. The action of the synthetic ZnONPs from the plant extract Argemone Mexicana against Aspergillus fumiga is determind. The maximum inhibition zone was observed at $5 \mathrm{~mm}$ for $25 \mu \mathrm{g}, 3 \mathrm{~mm}$ for $100 \mu \mathrm{g} / \mathrm{mL}$ concentrations. In Aspergillus fumigus, the zone increases as the concentration increases [32]. 


\subsection{Antioxidant Activity}

The activity of radicals of synthesized nano compounds is determined on the basis of the ability to scavenge stable DPPH radicals [33]. The antioxidant capacity of zinc oxide nanoparticles at different concentrations is calculated as a percentage inhibition of absorbance. DPPH is stable, free radicals that could accept either electron or hydrogen radicals in order to become a stable molecule. The reduction of DPPH of the rhodium is determined by the decrease in its absorbance caused by the antioxidant at $517 \mathrm{~nm}$. The concentration of the sample at which the percentage of inhibition reaches $50 \%$ is its $\mathrm{IC}_{50}$ value. The $\mathrm{IC}_{50}$ value is negative due to antioxidant activity because it expresses the amount of antioxidant needed to reduce the concentration of its radicals by $50 \%$.

\section{Conclusions}

Nanotechnology is the most promising technologies of the 21st century. It is used in several medical and biological applications. A green biosynthesis of zinc oxide nanostructure (ZNP) has been successfully applied under the influence of Argemone Mexicana (AML) leaf extract. Characterization of prepared $\mathrm{ZnO}$ nanostructures studied using a prominent analysis such as XRD, SEM, EDAX, FTIR and UV-vis. Spectroscopic analysis, etc. the crystalline, structural, morphological and spectral properties, using the results of the crystalline studies obtained, the formation of nano-crystalline structures of $\mathrm{ZnO}$ could be investigated. The observed spectroscopy analysis helps to reveal the function of the elemental composition. The analysis of EDAX reveals on its surface the existence of $\mathrm{Zn}$ and $\mathrm{O}$. The observed UV-vis analysis exhibited an absorption peak at $377 \mathrm{~nm}$ and provided the energy value of the $\mathrm{ZnO}$ nanoband gap at $3.2 \mathrm{eV}$. Biosynthetic nanoparticles of $\mathrm{ZnO}$ gave a strong level of anti-microbial activity against $E$. coli (negative grammatical bacteria) and Streptococcus aureus (positive grammatical bacteria) and a stronger antifungal activity reported in Aspergillus fumiga. Leaf extract as well as high ZnO NPs concentration gives high activity. It has been found that $\mathrm{ZnO}$ nanoparticles are synthesized to protect against bacterial and fungal pathogens, suggesting that they can be used as effective antimicrobial and antioxidant agents for commercial uses in biomedical applications and may be medical therapy for other future work and applications in industry.

Author Contributions: M.C.: Methodology of work and experimental, Y.S.: Methodology of work and experimental, F.B.: writing draft preparation and review the work and editing, M.R.: Methodology of work, C.S.: Data analysis, A.S.: Experimental work, G.G.: Computing data, M.P.: Computing work, U.R.: Methodology of work, experimental analysis and review, M.A.-R.: Supervisor of work. All authors have read and agreed to the published version of the manuscript.

Funding: This research received no external funding.

Institutional Review Board Statement: Not applicable.

Informed Consent Statement: Not applicable.

Data Availability Statement: All the Data is available with Authors.

Acknowledgments: Authors thank researchers, who are all support for the best outcome of this research work.

Conflicts of Interest: The authors declare no conflict of interest.

Sample Availability: Samples of the compounds are available from the authors. 


\section{References}

1. Bayda, S.; Adeel, M.; Tuccinardi, T.; Cordani, M.; Rizzolio, F. The History of Nanoscience and Nanotechnology: From ChemicalPhysical Applications to Nanomedicine. Molecules 2020, 25, 112. [CrossRef] [PubMed]

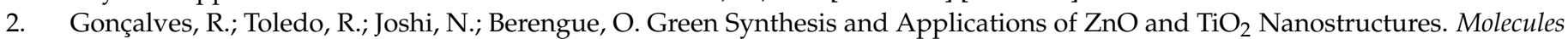
2021, 26, 2236. [CrossRef] [PubMed]

3. Patra, J.K.; Das, G.; Fraceto, L.F.; Campos, E.V.; Rodriguez-Torres, M.D.; Acosta-Torres, L.S.; Diaz-Torres, L.A.; Grillo, R.; Swamy, M.K.; Sharma, S.; et al. Nano based drug delivery systems: Recent developments and future prospects. J. Nanobiotechnol. 2018, 16, 71. [CrossRef] [PubMed]

4. Schultz, S.; Smith, D.R.; Mock, J.J.; Schultz, D.A. Single-target molecule detection with nonbleaching multicolor optical immunolabels. Proc. Natl. Acad. Sci. USA 2000, 97, 996-1001. [CrossRef]

5. Rai, M.; Yadav, A.; Gade, A. Silver nanoparticles as a new generation of antimicrobials. Biotechnol. Adv. 2009, 27, 76-83. [CrossRef]

6. $\quad$ Elechiguerra, J.L.; Burt, J.L.; Morones, J.R.; Camacho-Bragado, A.; Gao, X.; Lara, H.H.; Yacaman, M.J. Interaction of Silver Na-noparticles with HIV-1. J. Nanobiotechnol. 2005, 3, 6. [CrossRef] [PubMed]

7. Kritsanaviparkporn, E.; Baena-Moreno, F.; Reina, T. Catalytic Converters for Vehicle Exhaust: Fundamental Aspects and Technology Overview for Newcomers to the Field. Chemistry 2021, 3, 44. [CrossRef]

8. Gittins, D.I.; Bethell, D.; Nichols, R.J.; Schiffrin, D.J. Diode-like electron transfer across nanostructured films containing a re-dox ligand. J. Mater. Chem. 2000, 10, 79-83. [CrossRef]

9. Kinnear, C.; Moore, T.L.; Rodriguez-Lorenzo, L.; Rothen-Rutishauser, B.; Petri-Fink, A. Form Follows Function: Nano-particle Shape and Its Implications for Nanomedicine. Chem. Rev. 2017, 117, 11476-11521. [CrossRef]

10. Renuka, R.; Devi, K.R.; Sivakami, M.; Thilagavathi, T.; Uthrakumar, R.; Kaviyarasu, K. Biosynthesis of silver na-noparticles using phyllanthus emblica fruit extract for antimicrobial application. Biocatal. Agric. Biotechnol. 2020, 24, 101567. [CrossRef]

11. Kosikowska, U.; Wujec, M.; Trotsko, N.; Płonka, W.; Paneth, P.; Paneth, A. Antibacterial Activity of Fluorobenzoyl thiosemicarbazides and Their Cyclic Analogues with 1,2,4-Triazole Scaffold. Molecules 2021, 26, 170. [CrossRef]

12. Henglein, A. Reduction of $\mathrm{Ag}(\mathrm{CN}) 2$ - on Silver and Platinum Colloidal Nanoparticles. Langmuir 2001, 17, 2329-2333. [CrossRef]

13. Rodríguez-Sánchez, L.; Blanco, A.M.C.; López-Quintela, M.A. Electrochemical Synthesis of Silver Nanoparticles. J. Phys. Chem. B 2000, 104, 9683-9688. [CrossRef]

14. Zhu, J.J.; Liu, S.W.; Palchik, O.; Koltypin, Y.; Gedanken, A. Shape-Controlled Synthesis of Silver Nanoparticles by Pulse Sono-electrochemical Methods. Langmuir 2000, 16, 6396. [CrossRef]

15. Pastoriza-Santos, I.; Liz-Marzan, L.M. Formation of PVP-Protected Metal Nanoparticles in DMF. Langmuir 2002, $18,2888$. [CrossRef]

16. Begum, N.; Mondal, S.; Basu, S.; Laskar, R.A.; Mandal, D. Biogenic synthesis of Au and Ag nanoparticles using aqueous solutions of Black Tea leaf extracts. Colloids Surfaces B Biointerfaces 2009, 71, 113-118. [CrossRef]

17. Bar, H.; Bhui, D.K.; Sahoo, G.P.; Sarkar, P.; De, S.P.; Misra, A. Green synthesis of silver nanoparticles using latex of Jatropha curcas. Colloids Surfaces A Physicochem. Eng. Asp. 2009, 339, 134-139. [CrossRef]

18. Song, J.Y.; Kim, B.S. Rapid biological synthesis of silver nanoparticles using plant leaf extracts. Bioprocess Biosyst. Eng. 2009, 32, 79-84. [CrossRef]

19. Jain, D.; Daima, H.K.; Kachhwaha, S.; Kothari, S.L. Digest, Synthesis of Plant-Mediated Silver Nanoparticles using Papaya Fruit Extract and Evaluation of their Anti-Microbial Activities. J. Nanomater. Biostruct. 2009, 4, 557-563.

20. Saifuddin, N.; Wong, C.W.; Yasumira, A.A.N. Rapid Biosynthesis of Silver Nanoparticles Using Culture Supernatant of Bacteria with Microwave Irradiation. J. Chem. 2009, 6, 61-70. [CrossRef]

21. Bindhu, M.R.; Ancy, K.; Umadevi, M.; AliEsmail, G.; AbdullahAl-Dhabi, N.; ValanArasu, M. Synthesis and characterization of zinc oxide nanostructures and its assessment on enhanced bacterial inhibition and photocatalytic degradation. J. Photochem. Photobiol. B Biol. 2020, 210, 111965. [CrossRef]

22. Willner, I.; Basnar, B.; Willner, B. Nanoparticle-enzyme hybrid systems for nanobiotechnology. FEBS J. 2006, 274, 302-309. [CrossRef]

23. Toy, R.; Peiris, P.M.; Ghaghada, K.B.; Karathanasis, E. Shaping cancer nanomedicine: The effect of particle shape on the in vivo journey of nanoparticles. Nanomedicine 2014, 9, 121-134. [CrossRef]

24. Weissig, V.; Pettinger, T.K.; Murdock, N. Nanopharmaceuticals (part 1): Products on the market. Int. J. Nanomed. 2014, 9, 4357-4373. [CrossRef]

25. Brahmachari, G.; Gorai, D.; Roy, R. Argemone mexicana: Chemical and pharmacological aspects. Rev. Bras. Farm. 2013, 23, 559-575. [CrossRef]

26. Zhang, Y.; Nayak, T.; Hong, H.; Cai, W. Biomedical Applications of Zinc Oxide Nanomaterials. Curr. Mol. Med. 2013, 13, 1633-1645. [CrossRef]

27. Dressler, S.; Schmidt, M.; Ziizika, G. "Argemone Mexicana". African plants—A Photo Guide; Schungs Institute Senckenberg: Frankfurt, Germany, 2014

28. Kumar, D.S.; Sivaranjani, S.; Umamaheswari, M.; Ravikumar, B. Green synthesis of ZnO nanoparticles using Tra-chyspermum ammi seed extract for antibacterial investigation. Pharma Chem. 2016, 8, 173-180. Available online: http:// derpharmachemica. com/archive.html (accessed on 29 December 2021). 
29. Hudlikar, M.; Joglekar, S.; Dhaygude, M.; Kodam, K. Latex-mediated synthesis of ZnS nanoparticles: Green synthesis approach. J. Nanopart. Res. 2012, 14, 0865. [CrossRef]

30. AL-Asady, Z.M.; AL-Hamdani, A.H.; Hussein, M.A. Study the optical and morphology properties of zinc oxide nanoparticles. AIP Conf. Proc. 2020, 2213, 020007.

31. Bassyouni, F.; El Hefnawi, M.; El Rashed, A.; Rehim, M.A. Molecular Modeling and Biological Activities of New Potent Antimicrobial, Anti-Inflammatory and Anti-Nociceptive of 5-Nitro Indoline-2-One Derivatives. Drug Des. Open Access 2017, 6, 1-6. [CrossRef]

32. Bassyouni, F.; Tarek, M.; Salama, A.; Ibrahim, B.; el Dine, S.S.; Yassin, N.; Has-sanein, A.; Moharam, M.; Abdel-Rehim, M. Promising Antidiabetic and Antimicrobial Agents Based on Fused Pyrimi-dine Derivatives: Molecular Modeling and Biological Evaluation with Histopathological Effect. Molecules 2021, 26, 2370. [CrossRef] [PubMed]

33. García-López, J.I.; Zavala-García, F.; Olivares-Sáenz, E.; Lira-Saldívar, R.H.; Diaz Barriga-Castro, E.; Ruiz-Torres, N.A.; RamosCortez, E.; Vázquez-Alvarado, R.; Niño-Medina, G. Zinc Oxide Nanoparticles Boosts Phenolic Compounds and Antioxidant Activity of Capsicum annuum L. during Germination. Agronomy 2018, 8, 215. [CrossRef] 